\title{
Castration induces antiapoptotic effect during myocardial regional ischemia reperfusion
}

Najah R. Hadi ${ }^{1}$, Fadhil G. Al-Amran ${ }^{2}$, Maitham G. Yousif ${ }^{3}$, Kerar Kereem ${ }^{1}$

\begin{abstract}
Restoration of blood flow to ischemic myocardium results in the ischemia reperfusion (I/R) injury. This study was undertaken to investigate the potential role of endogenous testosterone in the regional ischemia reperfusion and apoptosis of the male rat hearts. Rats underwent surgical ligation of LAD and subjected to ischemia for $25 \mathrm{~min}$ and reperfusion for $40 \mathrm{~min}$, and 2nd underwent surgical castration, left $3 \mathrm{wks}$ for recovery, then underwent surgical LAD ligation. Blood samples were collected from the heart for measurement of plasma level of cardiac troponin I (cTn-I). The hearts were harvested, and divided into 3 sections, the 1st for the measurement of cardiac apoptosis level, the 2nd homogenized for measurement of tissue (TNF- $\alpha$, IL1- $\beta$, ICAM-1) and the 3rdwas fixed in $10 \%$ formalin for histological examination. Compared with the sham group, levels of tissue TNF- $\alpha$ \& IL-1 $\beta$, ICAM-1 and apoptosis; plasma cTn-I were increased $(P<0.05)$ in the control group, all control group rats showed significant myocardial injury $(P<0.05)$ compared with the sham group. Castration significantly counteracts the increase in myocardial levels of TNF$\alpha$, IL-1, ICAM-1, plasma cTn-I and apoptosis $(P<0.05)$. Histological analysis revealed that castration markedly reduced $(P<0.05)$ the severity of the heart injury in the rats underwent the regional ischemia-reperfusion procedure. This study reveals that surgical castration may ameliorate regional I/R injury and apoptosis in the ischemic heart in rats.
\end{abstract}

Keywords: Myocardial I/R, Castration, Cardiac apoptosis, Cytokines, LAD

*Corresponding Author: NajahHadi: drnajahhadi@yahoo.com

${ }^{1}$ Department of Pharmacology and Therapeutics, College of Medicine, Kufa University

${ }^{2}$ Department of Surgery, College of Medicine, Kufa University/ Kufa, Iraq

${ }^{3}$ College of Science, Al-Qadisiya University/ Iraq

Received 12 December 2013; accepted 22 February 2014

Copyright $\odot 2014$ NH. et al. This is article distributed under the terms of the Creative Commons Attribution License (http://creativecommons.org/licenses/by/2.0), which permits unrestricted use, distribution, and reproduction in any medium, provided the original work is properly cited. 


\section{Introduction}

Ischemic heart disease is one of the major leading cause of death for both men and women. Depriving the organ from its blood supply have long been recognized as a critical factor in the clinical outcome of stroke, hemorrhagic shock, myocardial infarction and organ transplantation. Although the restoration of blood flow to an ischemic organ is essential to prevent irreversible tissue injury, reperfusion may augment's tissue injury in excess of that produced by ischemia alone. Restoration of blood flow to ischemic myocardium results in the ischemia reperfusion (I/R) injury [1]. Cellular damage after reperfusion of previously viable ischemic tissue is defined as ischemia reperfusion (I-R) injury [2]. Reperfusion of ischemic tissue result in both a local and systemic inflammatory response that, in turn, may result in wide spread micro-vascular dysfunction and altered tissue barrier and function [3].

Gender differences have been noted in I-R injury [4, 5, 6, 7, 8, 9, 10], with several studies implicating the sex hormone estrogen in the cardio-protection found in females $[11,12,13,14,15]$. In contrast, testosterone has received little attention. Currently the majority of evidence points toward the detrimental effects of testosterone on myocardium, possibly by adverse effects on lipoproteins, thrombosis, and cardiac hypertrophy $[16,17,18,19]$. Indeed, some studies demonstrated that chronic endogenous testosterone has a deleterious effect in the isolated rat heart subjected to I-R [20]. Recent advances in our understanding of cell death during ischemia reperfusion implicate two form of the cell death in the pathology of myocardial infarction, namely necrosis and apoptosis [21]. Apoptosis cell death in rat heart has been demonstrated to be induced by prolonged episode of ischemia alone, in absence of reperfusion [22, 23]. Some studies have suggested that reperfusion accelerates the apoptotic cell death process initiated during ischemia [22, 24, 25, 26]. In contrast several studies suggest that the apoptotic component of cell death is triggered at time of reperfusion and does not manifest during the ischemic period [27].

Therefore, evidence suggests that the apoptotic component of cell death is either triggered or accelerated during the reperfusion phase. The fact that the apoptosis is an energy dependent process and ATP levels are depleted during ischemia and replenished on reperfusion may explain why the apoptotic component of cell death is associated with reperfusion [28]. 


\section{Method}

\section{Animals}

A total of 18 adult male albino rats weighting (200-250 g) were purchased from Animal Resource Center, National Center for Drug Control and Research. They were housed in the animal house of Kufa university/ College of Medicine in a temperaturecontrolled $\left(25^{\circ} \pm 1 \mathrm{C}\right)$ room (humidity was kept at $\left.60-65 \%\right)$ with alternating 12 -h light/12-h dark cycles and were allowed free access to water and chow diet until the start of experiments.

\section{Study design}

After the 1st week of acclimatization the rats were randomized into 4 groups( 6 rat in each) as follow:

1- Sham group: Rats underwent the same anesthetic and surgical procedures (for an identical period of time for regional myocardial ischemia and reperfusion ) but without LAD ligation.

2- Control group (induced untreated): rats underwent surgical operation for LAD ligation and subjected to $25 \mathrm{~min}$ of ischemia and $40 \mathrm{~min}$ of reperfusion.

3- Castrated group: surgically castrated rats left 4wks for recovery [20], then underwent surgical LAD ligation, and subjected to $25 \mathrm{~min}$ of ischemia and 40 min of reperfusion.

Surgical LAD ligation

The procedure of LAD ligation in rats is modified from that mentioned in previous study with modification [29]. The rats anesthetized by intra-peritoneal (IP) injection of $100 \mathrm{mg} / \mathrm{kg}$ ketamine and $5 \mathrm{mg} / \mathrm{kg}$ xylazine [30]. The left anterior descending coronary artery (LAD) is ligated just distal to the left auricle, the LAD is ligated with an 8-0 Prolene suture. The reperfusion time is calculated from the moment of removing the ligature, and the reperfusion is continued for $40 \mathrm{~min}$.

\section{Blood sampling for measurement of plasma cTnI}

Blood sample used for determination plasma cTn-I. By ELISA with a commercially available ELISA kit (Literature of kit by life Diagnostic, USA) according to the manufacturer's instructions.

\section{Myocardial TNF-a, IL-1B, ICAM-1, measurement}

The excised heart tissues was rinsed with ice cold saline to remove any red blood cells or clots, and homogenized with a high intensity ultrasonic liquid processor in 1:10 (w/v) phosphate buffered saline that contained $1 \%$ Triton X-100 and a protease 
inhibitor cocktail [31]. The supernatant was collected for determination of TNF- $\alpha$, IL$1 \beta$ and ICAM-1 by ELISA with a commercially available ELISA kit (Literature of kit by life Diagnostic, USA) according to the manufacturer's instructions.

\section{Tissue Sampling for Histopathology}

The cardiac sections [32] were stained with hematoxylin and eosin (H\&E) after fixation. Evaluate scores were performed by an investigator who was blinded to the experimental treatment groups.

\section{Myocardial apoptosis level measurement}

The part of ventricular samples that used for measurement of apoptosis level are underwent lyses by trypsin, which is a serine protease commonly used for detachment of adherent cell lines and dissociation of tissues. The measurement is done by ELISA with a commercially available ELISA kit (ssDNA ApoptosisELISA Kit,CHEMICON® International, Inc. USA).

Presentation of data and statistical analysis.

Data were expressed as mean \pm SEM. Quantitative variables were tested for statistical significance of difference between more than 2 groups by One-Way ANOVA test followed by Post Hoc. LSD test for multiple comparisons. Nonparametric tests were used to assess the statistical significance of histopathological parameter. The statistical significance of difference between more than 2 groups was assessed by Kruskal-Wallis test, while Mann-Whitney U test was used for the difference between 2 groups. In all tests, $P<0.05$ was considered to be statistically significant.

\section{Results}
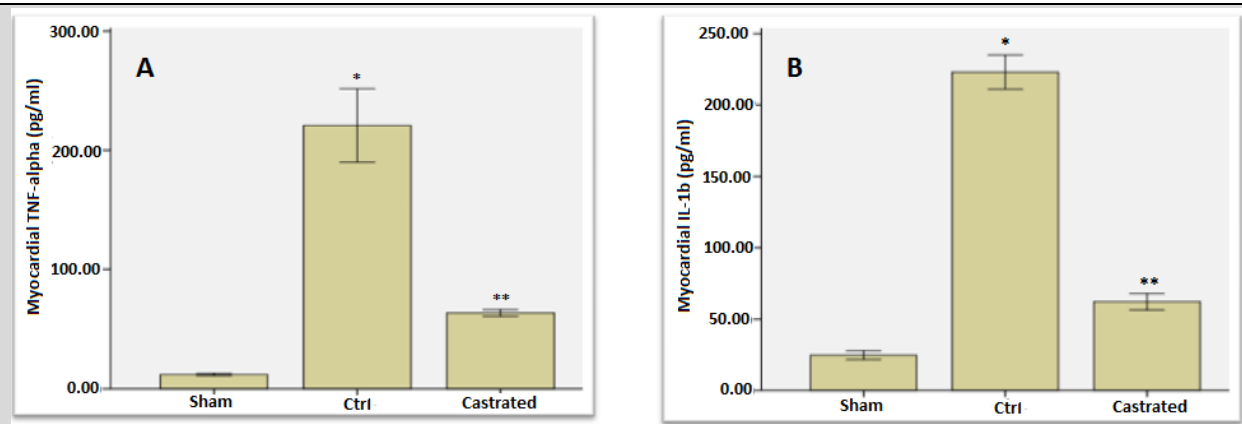

Figure 1.

The mean of myocardial proinflammatory cytokines level A) TNF- $\alpha, \mathbf{B}) \mathrm{IL}-1 \beta,(\mathrm{pg} / \mathrm{mg})$ in the experimental groups at the end of the experiment. ${ }^{*} P<0.05$ vs. sham group; ${ }^{*} P<0.05$ vs. Ctrl vehicle group. 

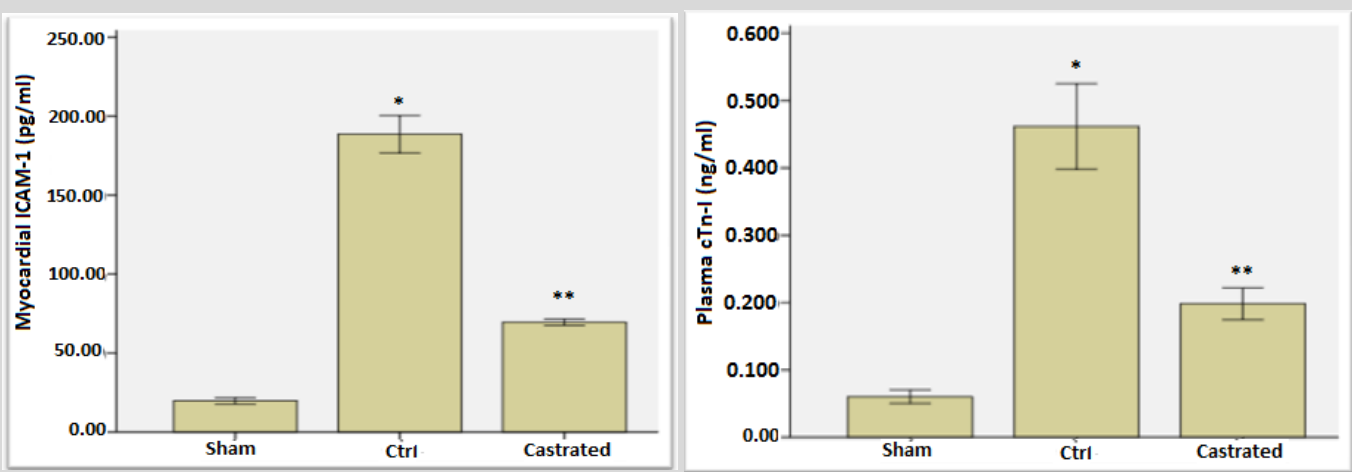

Figure 2.

The mean of myocardial ICAM-1 level ( $\mathrm{pg} / \mathrm{mg}$ ) (left side figure). The plasma mean of cTn-I (pg/ml) (right side figure) in the three experimental groups at the end of the experiment. $P<0.05$ vs. sham group, ${ }^{* *} P<0.05$ vs. Ctrl group.
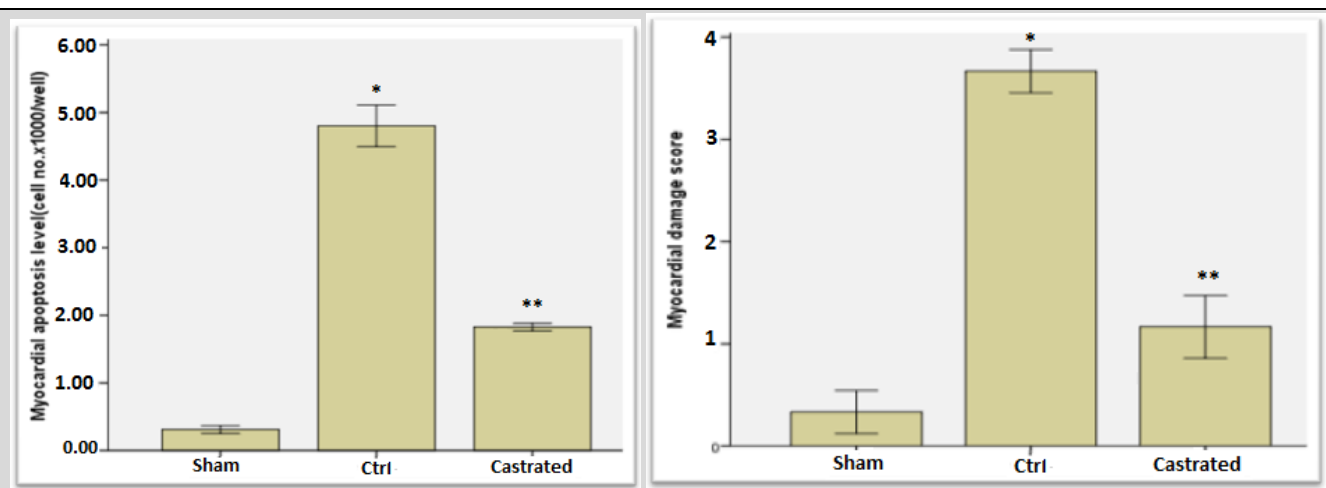

\section{Figure 3.}

Error bar the means of myocardial apoptosis level (left side fig.). Error bar chart shows the means of myocardial damage score (right side fig.) in the experimental groups at the end of the experiment three.
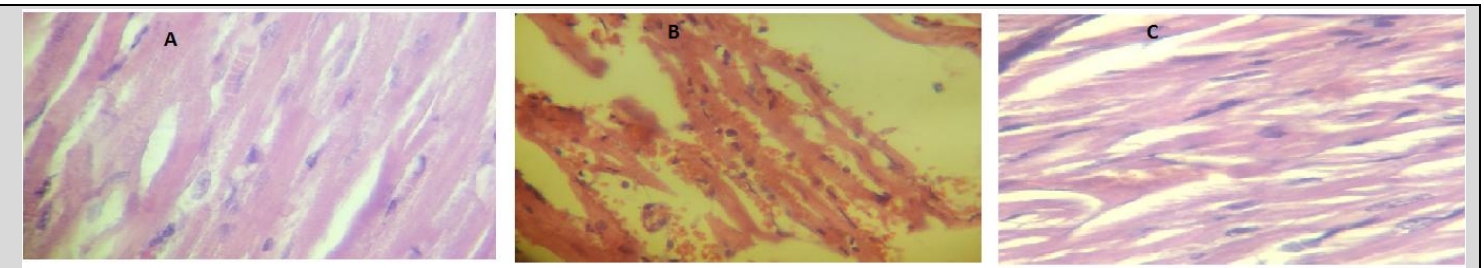

Figure 4.

Representative photomicrograph of a section of the heart tissue section stained with Haematoxylin and Eosin (X40). A) The sham group shows normal architecture. B) Photomicrograph of cardiac section for the control group showed hemorrhage, necrosis and neutrophil infiltration. C) Photomicrograph of cardiac section in castrated group show almost normal cardiac structure; most tissues reveal a mild histological change. 


\section{Discussion}

The role of testosterone in cardiac injury may be very important because the heart can accumulate testosterone at higher concentrations than other androgen target organs [34], and functional androgen receptors are present in isolated cardiac myocytes [35]. Testosterone was reported to confirm cardio protection against ischemia reperfusion by up regulating the cardiac alpha1-adrenoceptor and enhancing the effects of stimulation of this adrenoceptor [36]. On the contrary, other study hypothesized that testosterone may exert deleterious effects on myocardial pro inflammatory cytokine production through pro-inflammatory and/or the pro-apoptotic properties of endogenous testosterone in ischemia reperfusion [20]. Moreover, exogenous testosterone supplementation increased apoptosis in adult rat ventricular myocytes during I/R injury [37].

Zhao et al., (2001) have characterized, using a canine model of ischemia reperfusion injury, to study the contribution of necrotic and apoptotic cell death. They demonstrated that these two forms of cell death occur simultaneously during the reperfusion phase, with necrotic cell death peaking after $24 \mathrm{hr}$. of reperfusion, and apoptotic cell death increasing up to $72 \mathrm{hr}$. of reperfusion [38]. Other studies have demonstrated that the pharmacological inhibition of the apoptotic signaling cascade during the reperfusion phase is able to attenuate both the apoptotic and the necrotic component of cell death [39, 40, 41, 42]. They suggested that the apoptotic death process can evolve into necrotic cell death. Wang M, et al.(2005). Stated that testosterone may promote the inflammatory response, because myocardial inflammatory cytokines production ( TNF- $\alpha$, IL1 $\beta$, ICAM-1) decreased in castrated male rats and testosterone receptor blocker treated rat compared with non castrated males after acute myocardial I/R [20]. Wang et al. (2005) shows that castrated rat male subjected to I/R had decreased apoptosis level compared to sham group [20] . Paul et al. ( 2006) also demonstrated that in rat hearts devoid from chronic exposure to testosterone, a single dose of exogenous testosterone increase apoptosis level [43].

Findings in the present study according to apoptosis level are in agreement with above 2 studies. Clinically, myocyte apoptosis in heart failure is increased in men compared with women44. Some studies have demonstrated that anabolic androgenic steroids induce injury and apoptosis in myocardial cells $[45,37]$. 
Maria et al. ( 2006) showed that castrated male rats when subjected to the ischemia have significantly decrease in the severity of histological finding of ischemia so that there are less ischemic expansion and less neutrophil infiltration at the infarction border than the non castrated male control group [46].

\section{Competing interests}

The authors declare that there is no conflict of interest.

\section{Author Contributions}

All authors wrote, read and approved the final manuscript.

\section{References}

1. Meldrum DR. Tumor necrosis factor in the heart. Am J Physiol Regul Integr Comp Physiol 1998;274: R577-R595.

2. Carden DL, Granger DN. Pathophysiology of ischaemia-reperfusion injury. J Pathol 2000;190: 255-266.

3. Neary P, Redmond HP. Ischaemia-reperfusion injury and the systemic inflammatory response syndrome. In Grace PA, Mathie RT (eds) Ischaemia-Reperfusion Injury. Oxford: Blackwell Science 1999; 123-136.

4. Angele MK, Schwacha MG, Ayala A, and Chaudry IH. Effect of gender and sex hormones on immune responses following shock. Shock 2000;14: 81-90.

5. Kher A, Meldrum KK, Wang M, Tsai BM, Pitcher JM, and Meldrum DR. Cellular and molecular mechanisms of sex differences in renal ischemia-reperfusion injury. Cardiovasc Res 2005; 67: 594-603.

6. Kher A, Wang M, Tsai BM, et al. Sex differences in the myocardial inflammatory response to acute injury. Shock 2005; 23:1-10.

7. Meldrum DR, Wang M, Tsai BM, Kher A, Pitcher JM, Brown JW, Meldrum KK. Intracellular signaling mechanisms of sex hormones in acute myocardial inflammation and injury. Front Biosci 2005;10: 1835-1867.

8. Mendelsohn ME and Karas RH. Molecular and cellular basis of cardiovascular gender differences. Science 2005; 308: 1583-1587.

9. Wang M, Baker L, Tsai BM, Meldrum KK, Meldrum DR. Sex differences in the myocardial inflammatory response to ischemia/reperfusion injury. Am J Physiol Endocrinol Metab 2005; 288: E321-E326.

10. Wang M, Tsai BM, Brown JW, and Meldrum DR. Gender differences in myocardial apoptotic signaling and recovery following acute injury (Abstract). Shock 21, Suppl 2004; 2: 23.

11. Baker L, Meldrum KK, Wang M, et al. The role of estrogen in cardiovascular disease. J Surg Res 2003; 115: 325-344. 
12. Knoferl MW, Angele MK, Schwacha MG, Anantha Samy TS, Bland KI, Chaudry IH. Immunoprotection in proestrus females following trauma-hemorrhage: the pivotal role of estrogen receptors. Cell Immunol 2003; 222: 27-34.

13. Mendelsohn M Karas RH. The protective effects of estrogen on the cardiovascular system. N Engl J Med 1999; 340: 1801-1811.

14. Mizushima Y, Wang P, Jarrar D, Cioffi WG, Bland KI, Chaudry IH. Estradiol administration after trauma-hemorrhage improves cardiovascular and hepatocellular functions in male animals. Ann Surg 2000; 232: 673-679.

15. Szalay L, Shimizu T, Suzuki T, et al. Estradiol improves cardiac and hepatic function following trauma-hemorrhage: role of enhanced heat shock protein expression. Am J PhysiolRegulIntegr Comp Physiol 2006; 290: R812-R818.

16. Melchert RB and Welder AA. Cardiovascular effects of androgenicanabolic steroids. Med Sci Sports Exerc 1995; 27: 1252-1262.

17. Remmers DE, Cioffi WG, Bland KI, Wang P, Angele MK, Chaudry IH. Testosterone: the crucial hormone responsible for depressing myocardial function in males after trauma-hemorrhage. Ann Surg 1998; 227: 790-799.

18. Remmers DE, Wang P, Cioffi WG, Bland KI, and Chaudry IH. Testosterone receptor blockade after trauma-hemorrhage improves cardiac and hepatic functions in males. Am J Physiol Heart Circ Physiol 1997; 273: H2919-H2925.

19. Wu FC and von Eckardstein A. Androgens and coronary artery disease. Endocr Rev 2003;24: 183-217.

20. Wang M, Tsai BM, Kher A, Baker LB, Wairiuko G, Meldrum DR. Role of endogenous testosterone in myocardial proinflammatory and proaptoticsignalling after acute ischemia-reperfusion. Am J Physiol Heart Circ Physiol 2005; 288(1):H221-6.

21. Gottlieb RA, Engler RL. Apoptosis in myocardial ischemia-reperfusion. Ann NY Acad Sci 1999;874:412- 26.

22. Fliss H, Gattinger D. Apoptosis in ischemic and reperfused rat myocardium. Circ Res 1996;79(5):949- 56.

23. Kajstura J, Cheng W, Reiss K, et al. Apoptotic and necrotic myocyte cell deaths are independent contributing variables of infarct size in rats. Lab Invest 1996;74(1):86107.

24. Gottlieb RA, Burleson KO, Kloner RA, Babior BM, Engler RL. Reperfusion injury induces apoptosis in rabbit cardiomyocytes. J Clin Invest 1994; 94(4):1621-8.

25. Scarabelli TM, Knight RA, Rayment NB, Cooper TJ, Stephanou A, Brar BK, et al. Quantitative assessment of cardiac myocyte apoptosis in tissue sections using the 
fluorescence-based tunel technique enhanced with counterstains. J Immunol Methods 1999; 228(1-2):23-8.

26. Freude B, Masters TN, Robicsek F, et al. Apoptosis is initiated by myocardial ischemia and executed during reperfusion. J Mol Cell Cardiol 2000; 32(2):197- 208.

27. Zhao ZQ, Nakamura M, Wang NP, et al. Reperfusion induces myocardial apoptotic cell death. Cardiovasc Res 2000;45(3):651- 60.

28. Leist M, Single B, Castoldi AF, Kuhnle S, Nicotera P. Intracellular adenosine triphosphate (ATP) concentration: a switch in the decision between apoptosis and necrosis. J Exp Med 1997;185(8):1481-6.

29. Juan Zhang, Xiao-Xing Li , Hong-Jun Bian, Xiao-Bo Liu, Xiao-Ping Ji, Yun Zhang. Inhibition of the activity of Rho-kinase reduces cardiomyocyte apoptosis in heart ischemia/reperfusion via suppressing JNK-mediated AIF translocation.

Clinicachimicaacta; international journal of clinical chemistry 2008; 401(1-2):76-80.

30. Wiedemann D, Schneeberger S, Friedl P, Zacharowski K, et al. The fibrin-derived peptide Bbeta (15-42) significantly attenuates ischemia-reperfusion injury in a cardiac transplant model. Transplantation 2010; 89(7):824-9.

31. Zhang M, Xu YJ, Saini HK, Turan B, Liu PP, Dhalla NS. Pentoxifylline attenuates cardiac dysfunction and reduces TNF-alpha level in ischemic-reperfused heart. Am J Physiol Heart Circ Physiol 2005;289(2):H832-9.

32. Bancroft JD and Stevens A. Theory and Practice of Histological Techniques. 2nd ed. P.189. Churchill Livingstone. New York, 1982.

33. Zingarelli B, Salzman AL, Szabo C. Genetic disruption of poly (ADP-Ribose) synthetase inhibits the expression of P-selectin and intercellular adhesion molecule-1 in myocardial ischemia/reperfusion injury. Circ. Res1998; 83, 85-94.

34. Krieg M, Smith K, and Bartsch W. Demonstration of a specific androgen receptor in rat heart muscle: relationship between binding, metabolism, and tissue levels of androgens. Endocrinology 1978;103: 1686-1694.

35. Marsh JD, Lehmann MH, Ritchie RH, Gwathmey JK, Green GE, and Schiebinger RJ. Androgen receptors mediate hypertrophy in cardiac myocytes. Circulation 1998; 98: $256-261$.

36. Tsang $\mathrm{S}, \mathrm{Wu} \mathrm{S}$, Liu $\mathrm{J}$ and Wong TM. Testosterone protects rat hearts against ischemic insults by enhancing the effects of alpha (1) adrenoreceptor stimulation. $\mathrm{Br}$ J Pharmacol 1998; 153(4):693-709.

37. Zaugg M, Jamali NZ, Lucchinetti E, et al. Anabolic-androgenic steroids induce apoptotic cell death in adult rat ventricular myocytes. J Cell Physiol 2001;187: 9095. 
38. Zhao ZQ, Velez DA, Wang NP, et al. Progressively developed myocardial apoptotic cell death during late phase of reperfusion. Apoptosis 2001; 6(4):279-90.

39. Yaoita H, Ogawa K, Maehara K, Maruyama Y. Attenuation of ischemia/reperfusion injury in rats by a caspase inhibitor. Circulation 1998; 97(3):276- 81.

40. Mocanu MM, Baxter GF, Yellon DM. Caspase inhibition and limitation of myocardial infarct size: protection against lethal reperfusion injury. Br J Pharmacol 2000;130(2):197-200.

41. Holly TA, Drincic A, Byun Y, et al. Caspase inhibition reduces myocyte cell death induced by myocardial ischemia and reperfusion in vivo. J Mol Cell Cardiol 1999; 31(9):1709- 15.

42. Zhao ZQ, Morris CD, Budde JM, et al. Inhibition of myocardial apoptosis reduces infarct size and improves regional contractile dysfunction during reperfusion. Cardiovasc Res 2003; 59(1):132- 42.

43. Paul R. Crisostomo, Meijing Wang, George M. Wairiuko, Eric D. Morrell, Daniel R. Meldrum. Brief exposure to exogenous testosterone increases death signaling and adversely affects myocardial function after ischemia. Am J Physiol Regul Integr Comp Physiol 2006; 290:R1168-R1174.

44. Guerra S, Leri A, Wang X, Finato N, Di Loreto C, Beltrami CA, Kajstura J, Anversa P. Myocyte death in the failing human heart is gender dependent. Circ Res 1999; 85: $856-866$.

45. Welder AA, Robertson JW, Fugate RD, Melchert RB. Anabolic androgenic steroidinduced toxicity in primary neonatal rat myocardial cell cultures. Toxicol Appl Pharmacol 1995;133: 328-342.

46. Maria A. Cavasin, Zhen-Yin Tao, Ai-Li Yu, Xiao-Ping Yang. Testosterone enhances early cardiac remodeling after myocardial infarction, causing rupture and degrading cardiac function. Am J Physiol Heart Circ Physiol 2006; 290:H2043-H2050. 